\title{
Applying a regional land use approach to mine closure: opportunities for restoring and regenerating mine-disturbed regional landscapes
}

\author{
R Hattingh The University of Queensland, Australia \\ DJ Williams The University of Queensland, Australia
}

G Corder The University of Queensland, Australia

\begin{abstract}
Historically, mining companies needed to be good at one thing - mining. The end goal was also clear-mine the ore and walk away. However, as societal perspectives have shifted and communities have started to demand (and expect) functional post-mining landscapes with manageable residual liabilities, this linear business approach has needed to adapt.

Industry knowledge of the importance of the post-mining land use goal driving land rehabilitation objectives is becoming well understood. However, the capabilities of the rehabilitated land-ecologically, socially and economically, as well as stakeholder involvement in decision-making on what the rehabilitated land could supply, are considered a major challenge in mine closure planning. To edge closer to relinquishment, 'walk away' has turned into 'resilient substitute landscapes'.
\end{abstract}

This paper will discuss the fundamental need for integration of mine site rehabilitation into wider regional landscape planning, towards being able to create opportunities for restoring and regenerating mine-disturbed landscapes. A global perspective on current existing post-mining land uses will be provided, as well as key considerations for selection of these land uses. The importance of integrating site-specific rehabilitation plans within overarching regional land planning frameworks will also be discussed.

Keywords: land use, regional closure planning, resilient landscapes

\section{Introduction}

'Land use', by nature of the term, implies the way land is used by humans for a defined purpose. This purpose may result in one use (or activity), or a suite of uses. In most instances, one landscape can support numerous land uses which are often all inextricably interlinked; thereby creating a multi-functional, multidimensional landscape.

Changing land use demands on the land introduces new conflicts between competing needs for remaining natural resources, suitable uses of the land, specific interests of individual land users and the 'common good'. Land utilised for towns, mining and industry is no longer available for farming; likewise, the development of new farmland competes with forestry, water supplies and conservation initiatives.

From a mining perspective, this competing land use is especially evident in the coalfields of the developing nation of South Africa and the developed nation of Australia. Coal was first mined in the South African Central Basin, which includes the Witbank, Highveld and Ermelo Coalfields in the Mpumalanga Province, over 125 years ago. This Coalfield is still one of the most important in the country today (Hancox 2016). South Africa's economically recoverable coal reserves are estimated at between 15 and 55 billion tonnes and coal production in the Central Basin is likely to peak in the next decade (Benchmark Foundation 2014). In Australia, Queensland's coal mining longevity is just as evident, commencing in the Ipswich Coalfields over 150 years ago, in the Bowen Basin since the early 1970s, into the Surat Basin and soon into the Galilee Basin. 
Defining viable and appropriate post-mining land uses and ecological functions are core requirements of setting rehabilitation goals for mines in these areas, as many of them approach the end of their lifecycles. Global case studies of successful mine rehabilitation indicate the real possibility for lease relinquishment of land that either mimics pre-mining land uses, or delivers altered, new post-mining landscapes. However, mine land rehabilitation is still often undertaken in a site's planning vacuum. There is little consideration to alignment of site-specific rehabilitation targets to regional land use needs. A key regional land use need, or driver, or suite of drivers, provide the overarching planning context for a site's rehabilitation planning. This should focus mine effort and expenditure as rehabilitation can be directly aligned to, for example, land productivity, ecosystem functionality, urban development, or renewable energy drivers etc. depending on the regional needs and capacities.

As global populations grow and the subsequent need for more land for human development and settlement increases, the need for suitably-rehabilitated mined areas is becoming more evident. Mines occupy large fragments of regional landscapes and will need to be rehabilitated to a state that seamlessly blends their post-mining land uses within that of the larger, regional planning footprint.

This paper identifies current international post-mining land use trends and considers how these were selected for implementation. It will further assess the availability of global regional closure planning guidance, as well as key regional land use drivers that could be used to devise site-specific rehabilitation targets. All aimed at fostering development of opportunities for restoring and regenerating mine-disturbed regional landscapes.

\section{$2 \quad$ A post-mining land use perspective}

\subsection{Trends in global land use implementation}

Pre- and post-mining landscapes often differ dramatically from each other, with surface mining involving a twofold change in land use: from a pre-mining landscape to a mining landscape, and then from a mining landscape to a post-mining landscape. Unfortunately, pre-mining land use/s (which are still the predominant post-mining land use goal) remain technically, practically and financially challenging to recreate due to the significant alternation of the pre-mining landscape by the mining process and often poor rehabilitation practices or ongoing site maintenance.

For most mining companies, health and safety, and biophysical factors have had the greatest level of influence on post-closure land use decisions in the past. This is to be expected, as leaving the site in a stable and safe condition has long been the primary objective of rehabilitation plans. These are critical sustainability issues as well as being the factors most likely to lead to a legal liability if not well-managed.

Defining viable and appropriate post-mining land uses and ecological functions are core requirements of setting rehabilitation goals for mines in these areas, as many of them approach the end of their lifecycles. Case studies of successful mine rehabilitation, globally, indicate the real possibility for lease relinquishment of land that either mimics pre-mining land uses, or delivers altered, new post-mining landscapes.

Aligned to the requirements of local legislation, global governing standards, guidelines and policies and practical case studies, the following global post-mining land use implementation trends have been identified.

\subsubsection{Legislation and guidelines, and enforcement}

Historically and, for the most part, currently, global legislation and supporting guidelines require that minedout land be returned to a condition as close as possible to the pre-mining situation. In countries where mine rehabilitation and closure planning is more progressive, it is typically required that rehabilitation of mined land is to a condition that will minimise negative social and environmental consequence, towards sustaining an agreed end use (Maczkowiack \& Smith 2012).

There is a long history and awareness of the benefits of effective mine closure planning in Australia. All the States have jurisdiction-specific mine closure legislation. In general, the federal mineral acts provide statutory 
requirements enforcing the management and rehabilitation of the affected environment of mining. Detailed guidelines of mine rehabilitation and closure are also available for regional guidance (Kabir et al. 2015). Although Australia appears to currently have some of the most comprehensive mining-related rehabilitation and closure legislation and guidelines in the world, as well as a developing base of risk-based post-mining land use research (Maczkowiack et al. 2012; Tibbet et al. 2012; Doley et al. 2012; Cummings 2014; Kabir et al. 2015), comprehensive measures of the long-term success and sustainability of these rehabilitated landscapes, and ultimate mine closure certification and post-mining land usage, remain elusive.

Canada provides a high level of detailed mine closure-related legislation and specific guidelines which are regularly updated. Under the Canadian federal system, responsibility for mining falls within the exclusive domain of the provinces. Most provinces have a detailed guideline for mine closure, providing practical onsite guidance. However, focus still needs to be placed on identifying suitable alternatives for post-mining land use, better defining post-closure social and community needs, and long-term human and financial responsibilities around performance assessment (rehabilitation monitoring) and implementation of corrective action (Kabir et al. 2015).

In the United States of America (USA), the national Surface Mining Act contains a long list of performance standards, which include restoration of land to a condition capable of supporting pre-mining uses, or acceptable higher or better uses (Danielson \& Nixon 2010). The general principle underlying the country's laws is that the choice of post-mining land use resides with the private landowner and is not subject to dictation by government, except to the extent that any land is subject to local zoning, planning, or other land use regulations. Specifically, the closure authority concerns itself not with the end, but with the means, i.e. how the plan provides sound technical means to achieve the final land use (Comp 2013).

Both Canada and the USA have long histories of mining. Although this has resulted in abandoned mines in all jurisdictions (Boyer 2015), it has also improved the active integration of community engagement into closure planning within mining project planning (Comp 2013).

In accordance with the German Federal Spatial Planning Act, mining land use plans are jointly developed as part of municipal and regional spatial plans, ensuring an integrated regional land use framework. The aim is the optimal spatial planning and development of the regions, incorporating the disciplines of ecology, economy, settlements and infrastructure (Isolde 2009). Land use planning in Germany is being undertaken as a multi-disciplinary approach aiming to identify future land use solutions that provide places to live, produce food, supply recreational areas, or help mitigate climate change or temperature rise (which is a top priority of Saxon state regional planning efforts) (Larondelle \& Haase 2012).

Local environmental legislation in China appears fragmented, with little guidance on rehabilitation or re-use of mining land, especially for those that are historically derelict or abandoned. The required standards for ecological restoration are low (Wang 2012). However, within the last decade there has been a more vigorous call to put management of environmental impacts posed by mining, ahead of the mines' contribution to national economic growth (Cao 2007). This call has emphasised that while there will be a continued effort to speed up development of mine districts, the land should be reclaimed not only to raise the utilisation rate of land resources and keep the dynamic balance of the total farmland area, but also to restore the ecological balance and promote the sustainable development of ecology, economy and society (Wu et al. 2011).

The Latin American countries experience a developing world contradiction of mining revenues being very high, but mining areas remaining very poor (Jeronimo et al. 2015). Although current national Latin American mine closure legislation shows a steady evolution of the legal aspects related to the requirement of measures for rehabilitation of degraded areas, there still is a lack of drivers for integrated mine closure, stakeholder engagement, or consideration of the social impacts of mine closure.

Africa-and South Africa specifically-have tried to incorporate global trends along with its main goal of transformation and rectification of historical injustices (Brumfitt 2013). However, as with many developing countries, the nature, depth and strength of much of the available legislation and the ability to monitor and enforce associated obligations varies notably between countries and even within regions within one country. As regulatory authorities are still reluctant to grant closure certificates, mining companies are selecting post- 
mining land uses that offer the greatest likelihood of relinquishment, rather than the most sustainable land use. Unfortunately, where regulatory enforcement is lacking, and turnover of already inexperienced regulators is high, actual implementation towards successfully rehabilitated landscapes is improbable.

In general, there is a plethora of well-written, up-to-date legislation, standards and guidelines governing mining-related rehabilitation and closure in both developed and developing nations. However, in developing countries, governing legislation often does not appropriately align across regulatory departments, creating an uncertainty as to who the key regulatory authority is and with whom regulatory-industry relationships should be established. In addition, there is often an overlap in regulatory requirements, with mining companies required to submit numerous documents that could, in effect, be dealt with cumulatively. This duplication results in unnecessary time wastage of on-the-ground teams, as well as non-integration of postmining vision, objectives and actions across all the documents. Conversely, developed countries, like Australia, the USA, Canada and Germany, tend to combine resources of both regulators and industry in finding appropriate rehabilitation solutions (Morrison-Saunders et al. 2014).

\subsubsection{Implemented land uses}

Although perceptions of post-mining landscapes are often negative, they can harbour unique natural, cultural and economic potential (Kivinen 2017). Acceptance that mining-related land use planning requires a multidisciplinary approach enables harnessing of out-the-box opportunities for the rehabilitated landscapes. To date, sometimes seemingly outlandish proposals have been used to create vibrant landscapes which would otherwise have fallen into or remained in disuse. The book 101 Things to Do with a Hole in the Ground by Georgina Pearman (2009), published by the Post-Mining Alliance in association with the Eden Project, provides international successful, practical examples of re-created post-mining land uses that have often been generated from out-the-box concepts but, with good planning, have proven to be highly successful. In addition to these examples, the following implemented post-mining land uses have also been identified.

In Australia, there is a mix of land uses that appear to harness the vast spaces and warm climates of the area. In a country which has a relatively low population density with many of the larger mining operations situated far from dense urban areas, current rehabilitation practices aim to achieve a range of beneficial ecosystem services via the reintroduction and conservation of native biodiversity (Morrison-Saunders et al. 2014; Tibbet et al. 2012; Minerals Council of Australia 2016). Grazing is also a commonly identified post-mining land use (Bowie \& Fulcher 2017), as many of the mining operations are located on land previously used for cattle grazing.

In Canada and the USA, the concept of devising rehabilitation measures that mimic functions in nature appear to be a driver of mining and heavy industry-related rehabilitation (Polster 2011). Much of this pertains to restoration of ecological functionality. In remote mining areas, cattle or other farming remains a predominant land use of areas adjacent to mining operations.

In Europe, as for other densely populated developed nations, mines that have operated close to highly populated areas, or having surrounding communities are often converted to cultural or recreational land uses. Museums, tourism destinations, restaurants, sporting facilities and/or concert areas appeared to be popular land use choices in and around urban hubs (Kivinen 2017; Bowie \& Fulcher 2017; Sudo 2017; Palmer 2016). In areas on the outskirts of urban developments, or in more rural settings, many mines have been retrofitted to support new industrial infrastructure or activities, such as scrapyards, sawmills, chemical processing facilities and waste treatment plants (Kivinen 2017).

Other developed nations also show numerous education/tourism land uses in the form of museums and industrial-related heritage resources, indicating a focus on using historic mining sites for establishment and continuation of cultural knowledge (Bowie \& Fulcher 2017; Sudo 2017; Palmer 2016).

Developing nations' post-mining land use case studies appear to focus on food production, in various forms of agriculture and aquaculture (Botha 2014; D'Souza et al. 2003; Otchere et al. 2004). This seems relevant, as food security remains a priority in national planning throughout Africa. In Mongolia, at Peabody Coal's Ereen Coal operation, a large portion of the reclaimed land was turned into hay paddocks that the local 
herding community can harvest for their own herds or sell for income. Local herders also serve as environmental monitors, providing them with an additional income stream (Van Zyl et al. 2016).

In South Africa, previously implemented post-mining land uses seem to have been retrofitted to the closed mine sites. This could indicate that these land uses were implemented in hindsight, with limited pre-planning. For example, many of these uses relate to recreation/sport (such as fishing) or aquaculture in remaining voids, biodiversity in pre-mining ecological areas (Binns \& Nel 2003); farming in pre-mining farming areas (Chaminuka et al. 2014; Pijpers 2014; Limpitlaw \& Briel 2013); and cultural tourism around historic mining features such as the Kimberly Big Hole. However, conversely to previously implemented land uses, examples of land uses currently being planned indicate a shift towards regional planning needs (of the people), such as bioenergy, solar and hydropower schemes to cater for rising urban energy needs (and rising coal-related energy costs), carbon sequestration to counterbalance greenhouse gas emission targets, and ecosystem goods and services' protection in ecologically sensitive areas.

Across the developed and developing nations, there is a surge in land uses related to renewable energies such as solar (Choi \& Song 2016; Song \& Choi 2016), bioenergy (Marra et al. 2013; Marvey 2009) and pumped hydro-storage facilities (Latimer \& Hannam 2018; Hall 2018). Approval has also recently been given for the re-purposing of a zinc mine in Australia to develop a below-ground air-storage cavern for emissions free compressed air energy storage (Australian Renewable Energy Agency 2019). Progressive improvements in eco-efficiency are also increasing on post-mining agendas, focusing on doing more with less through sustainable building, recycling, re-use and product substitution (Dale et al. 2000).

Interestingly, reprocessing of remaining waste rock and tailings has also begun in earnest in many countries. This is seen as a way to extend operational life, reduce the footprint of these facilities and improve management of potential long-term environmental liabilities, both from a site and regional land use perspective. Opportunities for refined processing, making of bricks and ceramics, cement additives or road aggregate are all being investigated, aimed at reducing mining footprint liabilities and generating additional income streams (Sibanda \& Broadhurst 2018; Lottermoser 2011). One of the most successful economic projects in using tailings as a resource is the Ergo Project, which involves large-scale gold tailings hydraulicing and reprocessing in the Johannesburg area of South Africa. The project was established in the 1980 s and has gone through multiple renewals. After removing the tailings and recovering gold and uranium, the land is made available for housing developments. The remaining tailings are deposited in a consolidated tailings facility south of the city (Van Zyl et al. 2016).

\subsubsection{Regional planning focus}

In areas dominated by mining, the need for a wider regional planning approach as opposed to site-specific plans has been coming to the forefront in the recent decade. Long-term water treatment and impacts on community livelihoods post-mining remain at the forefront of this regional planning drive.

In Australia, each state has a strategic business plan, supported by a strategic regional land use plan. These plans are used to devise the best approach to balancing strong economic growth whilst sustainably managing available natural resources across the regions. For example, NSW 2021, the Government's 10-year strategic business plan for New South Wales (NSW), supports an increase of 30 percent in the value of both primary industries and mining production by 2020 , an increase in the share of jobs in regional NSW, an increase in the population of regional NSW, the protection of strategic agricultural land and improved agricultural productivity. Alternatively, the Queensland State Planning Policy, 2017 focuses on liveable communities and housing, economic growth, environment and heritage, safety and resilience to natural hazards and infrastructure development. These State-driven plans merge regional requirements for economic, environmental and social long-term planning objectives.

Jones \& Maclean (2013) note that reclamation in the oil sands industry within the USA and Canada has, to date, primarily examined landscape elements in isolation and is now beginning to consider ways to integrate rehabilitation planning within the broader planning framework. Focus is being put on planning that includes all oil sands operators in a regional rehabilitation plan towards adequately addressing collaborative goals for 
future regional land use. However, there is evidence that regional land use planning is being undertaken more from a watershed or catchment perspective, driven by the need for long-term water supply to urban areas (Norman et al. 2012; Lilieholm et al. 2012); or from an ecosystem goods and services perspective (Woodruff \& Bendor 2016; Dale et al. 2000).

Germany remains as one of the few countries that have a dedicated document for 'regional' land use planning which considers most aspects of natural resource-, socio-economic-, climate change-related drivers - Land Use Planning Concept, Tools and Applications (German Federal Ministry for Economic Cooperation and Development 2011). This document, although having an underlying urban development theme, also highlights how mine closure in the country appears to be viewed as an opportunity to change both industrial and urban structures in a future-oriented way. Instead of industrial waste land, planning is being put in place to ensure that former mining areas are regenerated towards contributing to the future economic and social wellbeing of the areas. The Leibniz Institute of Ecological and Regional Development (IOER) in Dresden is, by the nature of its name, one of the few places in the world with a defined focus on regional landscape planning (Isolde 2009).

In Brazil, the mining company Vale has developed a regional closure approach for its iron ore operations (Resende et al. 2014). The company's mines were delineated in terms of homogenous catchments, geological macro compartments (mining seams or areas) and geomorphic structures. The mines were then classified based on their size and corresponding level of employment within the region. Municipalities were also classified in terms of whether they were leading or supporting governance bodies, within either miningspecific or diversified economic bases. Importantly, the outcomes of implementing the regional planning approach were mainly positive, emphasising the ability to create synergies between individual mine's socioenvironmental programmes, improved site management, reduced operating and closure costs, simplified environmental licensing procedures and enhanced stakeholder relations. More importantly, their regional closure planning has resulted in development of a 'master mine closure plan' for the entire territory (Picarelli et al. 2014).

In South Africa, the Department of Mineral Resources (DMR) acknowledged the cumulative extent of miningrelated impacts on both the biophysical environment and social structures. In 2007 the Department published a discussion document on sustainable development in the minerals sector which included the need for development of regional mining and closure strategies. This document highlighted the need for mining activities to be integrated within the developmental plans of the region in which it is located, as agreed with regional stakeholders. From a sustainability perspective, these regional plans would assist not only in aligning economic contributions in a region, but also to prevent irreparable environmental and social damage to the region. Unfortunately, to date, only a Draft Strategy for Regional Mine Closure in the Witwatersrand Gold Mining Areas (Department of Minerals and Energy 2008) has been published for industry use and is poorly utilised by either regulators or industry.

\subsubsection{Ongoing research and development}

Ongoing research and development are key in maintaining an understanding of current regional and local planning needs, as well as improved or more efficient mechanisms to implement these. Across the globe, although there are published examples of planned and implemented post-mining land uses, this literature is often more than 10 years old. Many of these sources are considered outdated. There is also very limited follow-up information on implemented case studies. From an industry perspective, information may be available, but it is not easily accessible and/or even documented or published. Most of this information remains either archived still in paper form in industry archives, or 'within the heads of the gurus at the time'. This provides restricted knowledge on suitability for implementation, possible challenges and opportunities faced, as well as how success could be determined. Ultimately, there are very few examples that could be used as 'text-book case studies' against which other mines could base their own post-mining land use planning. 
Interestingly, most published literature can be clearly zoned to certain regions, with the Australia, Canada the USA and Europe having the most available case studies. This may be purely due to the availability of human resources and financial capital to be directed to devise and implement best practice rehabilitation and land use projects, which is often not available in developing nations. In developing regions, many countries lack public institutions that have strong technical skills and are financially efficient, both of which are required for effective land use planning (Evidence and Lessons from Latin America 2010). Some of these governments have produced useful information for land planning, but that this has not necessarily led to implementation. Where governments are working in a more collaborative way, synergies are generated during the information collection process. It also appears that larger global corporations operating in these regions are implementing their global good practice corporate policies which are applicable across all the jurisdictions in which they work. In general, these policies are generally well beyond country-specific legislative requirements but are used to limit long-term company risks and financial liabilities. Figure 1 summarises the post-mining land use trends identified in this section.

\subsection{Summary of key considerations for post-mining land use implementation}

From the available literature and case studies, the following aspects have been identified as being key considerations for post-mining land use implementation, applicable to global operations:

The type of post-mining land use selected is highly dependent on the proximity of populated areas to the mine. The closer to rural or urban hubs, the more likely the post-mining land use can be developed within the town's ongoing land use plans. For sites located greater distances from urban hubs, long-term physical safety and environmental health will remain rehabilitation priorities.

The type of post-mining land use selected is also highly dependent on the 'environmental hazard rating' of the mined-out resource. Inert platinum waste rock dumps can be used by both people and animals if made safe and stable, but hazardous uranium tailings residues will need ongoing site access management. Similarly, development of urban infrastructure should not take place above shallow underground mining areas, in the event of surface subsidence or sinkhole formation. Nor should heavy infrastructure be developed on unconsolidated backfilled spoils. However, suitably covered backfilled voids provide good footprints for agricultural activities. This is similar for the re-use potential of surface infrastructure, e.g. gold processing facilities will need to be decontaminated, dismantled and removed, but diamond-related processing infrastructure could be retrofitted for a multitude of uses.

Aligned to the above, the importance of understanding a site's rehabilitation-related residual and possible latent risks is imperative in devising the safe use of a post-mining landscape. Examples include potentially unsafe surface structural conditions associated with underground mining methods; surface expression or decant of poor quality underground water; acidification of placed topsoil due to underlying acid-generating waste material resulting in die-off of established vegetation; structural stability, settlement and changes to surface topography of backfilled open pits and rehabilitated dumps; or spontaneous combustion from reclaimed waste dumps.

The ability of mining operations to achieve predefined post-mining land use/s is largely dependent on the manner in which rehabilitation is undertaken onsite. In many cases, rehabilitation practices are not sensitive to the specific actions required to implement successful land capabilities that underpin the predefined land use/s (specifically for food production-related land uses such as agriculture). This highlights the importance of defining suitable upfront post-mining land uses, against which rehabilitation practices can be established. This would also result in significantly less 're-rehabilitation' of mine sites. 


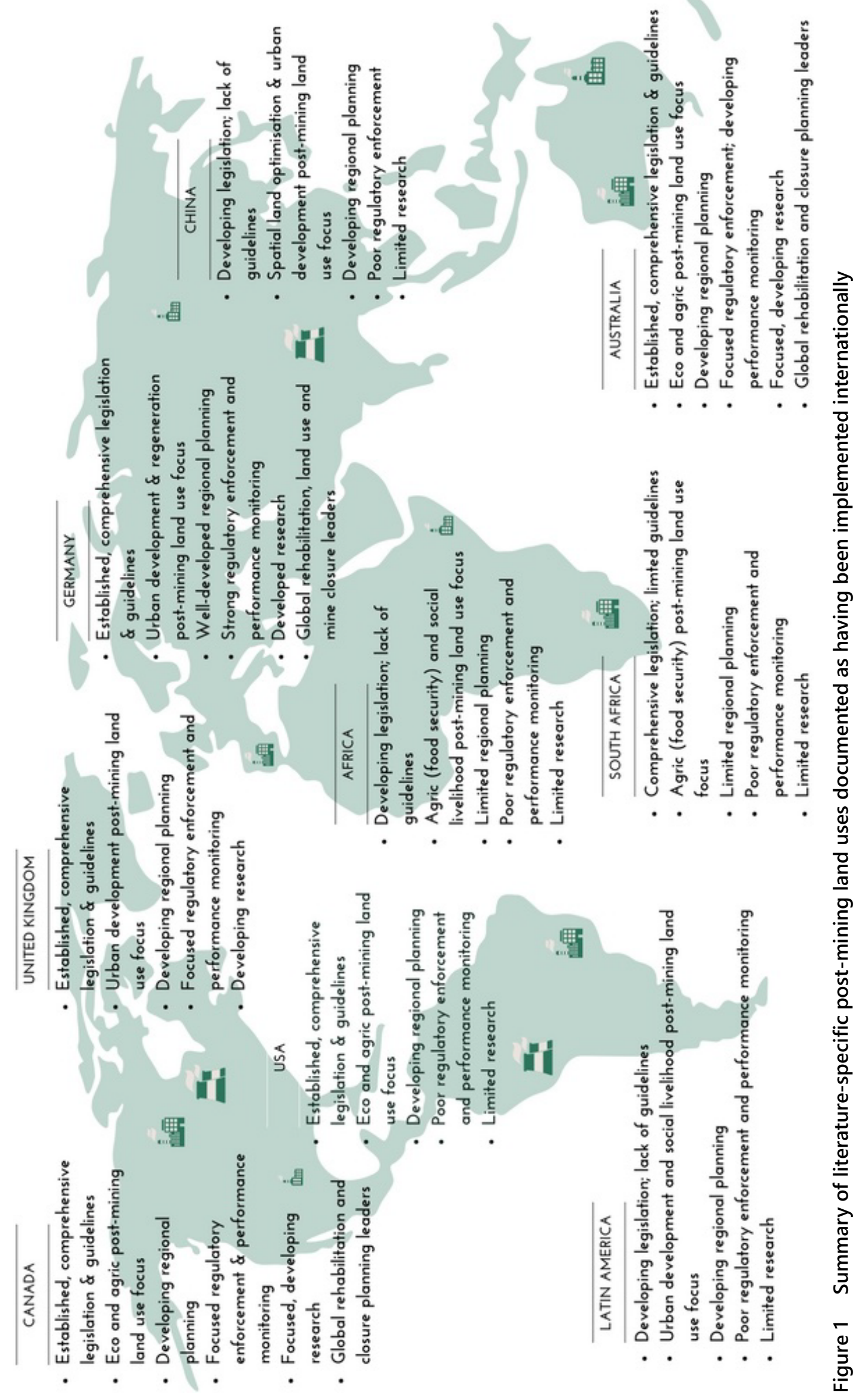


Rehabilitation of mined-out land is a science not well understood since it integrates many different scientific disciplines which encompass interrelationships over spatial and temporal scales that are often either neglected as part of planning, or just too complicated to correlate. This complexity is exacerbated by the uncertainty of how long-term climatic changes could affect not only implemented land uses, but also the functionality of the rehabilitated landscapes over time. This uncertainty requires attention to design rehabilitation criteria that can 'safely fail' instead of the previous and current design philosophy of 'fail-safe'. Ultimately, post-mining land use implementation can be much more successful and sustainable if it is recognised as a multi- and interdisciplinary field in both spatial and temporal contexts and receives the necessary attention it deserves.

With continually improving technologies, reprocessing of rehabilitated waste facilities or re-mining of old mine sites becomes more probable. The likelihood of this will need to be assessed on a site-by-site basis to focus rehabilitation spend on areas most likely to have a long-term, undisturbed re-use potential.

The earlier the post-mining land use is identified for an operation, the greater the likelihood of stakeholder buy-in and successful implementation and the lower the required human and financial resources needed to manage and maintain the landscape.

\section{Regional land use planning for mine closure}

\subsection{Building a regional landscape with all the pieces}

A critical challenge for land use planning involves reconciling conflicting national, regional (state or municipal) and local (site-specific) goals and uses of the land by all stakeholders into an (unpredictable) future. Local and regional perspectives on the benefits and costs of land management exacerbate the difficulty of these decisions (Dale et al. 2000). Expectations on the land from regulators, industry and communities surrounding mining areas can vary greatly and, in the end, a compromise suitable to all stakeholders will never be fully possible (Lane and Ndlovu 2012). Desires on a mining operation can vary significantly, as well as the way challenges arising from expectations not being met can manifest. The often-incompatible requirements on the land emphasise that reconciling conflicting national, regional and local land use goals is a highly complex issue facing mining-related land use planners.

However, post-mining land use planning has the ability to reinstate significantly large functional areas when considering the planning from a regional perspective. Although mines operate within the confines of the licenses, permits and authorisations related to their mining rights' areas, many large mining houses cover expansive footprint areas and/or comprise numerous operations that occur within one area. These are often interspersed operations that face similar challenges, impacts and residual risks. These 'regional linkages' provide an opportunity for dedicated land use and mine closure planning over much larger scales, enabling possible mitigation of cumulative environmental and social impacts in a focused, coordinated manner. It also provides an opportunity for integrated management/conservation of 'sensitive' social, ecological and economic communities from an overarching perspective. This could result not only in mitigation of ecological habitat fragmentation/corridor creation, but also reinstatement of larger expanses of functional agricultural land and the possible development of human settlement towards creating identified post-mining sustainable livelihoods.

Bloodworth et al. (2009) highlight that the minerals industry is unique in being able to provide suitable habitat mosaics and reverse habitat fragmentation through restoration. Good-quality restored areas create secure sites for biodiversity to develop and can provide other important ecosystem services such as flood management, carbon sequestration and food pollination. If active mining site management and rehabilitation can be coordinated on a landscape scale, the vulnerability of isolated habitats and species populations can be reduced, and additional ecosystem services provided.

A study undertaken by De Groot (2005) showed that sustainable, multi-functional use of natural and semi-natural landscapes often exceeds the gains from their conversion to single purpose land uses. Natural landscapes commonly provide a multitude of functions and are subject to many possible land uses. Also, for 
any particular land use, certain areas are better suited for some uses than others and different land uses should be matched to yield the greatest benefits at the lowest cost. Hence, it makes sense than mine closure planning should attempt to create a suite/multiple land uses over the rehabilitated landscape so that a level of sustainability more closely approximating that of the pre-mining landscape can be achieved. This does not imply recreating exact pre-mining land uses, but rather harnessing the altered landscapes' new characteristics to optimise services to communities that either provides similar resourcing needs from the land, or alternative resources that contribute to the long-term economic viability of the area.

Unfortunately, many land use assessment approaches at the regional scale over the last 15 years are based on highly complex models that require a high degree of parameterisation for which data are lacking (Larondelle and Haase 2012). Mine closure planning undertaken by the mining company Vale in Brazil further highlight the 'wicked problem' of land use planning in that the larger the planning project, the more local municipalities and stakeholders requiring interaction with, and the greater the dependence, complexity and risks associated with the planning and eventual closure (Picarelli et al. 2014).

However, even within the complexities of cross- and multi-disciplinary planning environments, this holistic approach to mining-related rehabilitation planning provides several benefits. A clear, early strategy for eventual rehabilitation could reduce the need for mineral or waste re-work, and progressive, proactive mitigation and management of impacts can reduce overall costs. Of course, a mine site can operate for many years, so it is vital that any consultations, agreements, commitments and arrangements are progressively recorded, and that there is ready access to this information during the rehabilitation phase.

\subsection{Water versus food versus shelter: defining the regional planning domain}

Land use planning begins with determining nature's arrangement of landscape elements and land cover and then considering models of optimal spatial arrangements and existing human uses. For such planning, understanding the spatial and temporal planning domain which the mine will be/is operating in and the associated longer-term human needs identified for the rehabilitated landscape is considered a critical step in a mine's lifecycle planning. However, rehabilitation is still often undertaken in a site's planning vacuum. There is little consideration to alignment of site-specific rehabilitation targets to regional land use drivers such as:

- Understanding the drivers for long-term water conservation, including possible treatment options to ensure acceptable water quality, future demands for water and the potential to re-use pits as water bodies for water supply and recreation.

- Understanding the regional capacity to supply food, which could prompt the reinstatement of productive, agricultural land.

- Understanding the regional capacity to maintain ecological function and diversity, including tourism potential.

- Investigating current and long-term energy demands, towards identifying possible land uses that could supplement local and/or regional power and energy grids.

- Understanding future human settlement patterns and land uses to identify possible land and/or infrastructure that could contribute to rural and/or urban development needs.

- Understanding the underpinning socio-economic context of the rehabilitated land, towards creating post-mining activities that could replace or enhance the mining industry's economic contribution and societal functionality within the area.

The key regional land use need, or driver (or suite of drivers), provide the overarching planning context for a site's rehabilitation planning. For mines located in close proximity to urban hubs, such as Australia's Ipswich Coalfields, rehabilitation can be focused on landform design, health and safety and infrastructure development, and not necessarily on natural resource conservation (as growth medium deficits would not be an issue here). However, for mines located in proximity to regional agricultural areas, such as South 
Africa's Witbank Coalfields, soil conservation and water harvesting will become key land rehabilitation components, aimed at optimising land productivity.

The following section highlights the key aspects around regional land use drivers that could help define a site's rehabilitation targets.

\subsubsection{Water conservation and preservation}

Mining is a water-intensive activity that is intrinsically exploitative of water resources and water-based ecosystems, most often altering both the quantity and quality of water flows. During operations, the impacts on groundwater aquifers and surface water resources relate predominantly to water volumes, with open pits and underground mines often dewatered below regional groundwater levels to ensure safe operating conditions. This pumped water is usually incorporated within minerals processing activities during operations and hence cannot contribute to local catchment integrity during the operational phase. As a site nears decommissioning, focus changes to measures required for long-term water quality management. This typically involves some form of intensive water treatment before it can be re-used and/or released into local water resources. Both the pumping, temporary storage and re-use and treatment of water resources affected by mining contribute a substantial portion of the site's rehabilitation costs.

Gulati et al. (2013) highlight that in future, specifically in water-scarce countries, crop choices will be largely reliant on water availability and its effect on food security. From a water-energy-food nexus perspective, water scarcity will also affect food production indirectly through competing with energy production, which will lead to trade-offs with the energy and resources sectors. Increasing water pollution also means that food producers will find it difficult to meet regulatory requirements of food safety and quality norms.

To conserve water resources into the future, land uses that contribute to protecting water resources and maintaining good soil structure to encourage infiltration rates and water quality, should be prioritised (Weatherhead \& Howden 2009).

\subsubsection{Land productivity (food security)}

The competition for natural resources is often most visible where mining and agriculture compete for high value agricultural land (Bureau for Food \& Agriculture Policy 2015). To date, most land within an allocated mining rights' area is not available for other land uses during the mine's operational life. However, although mines are not in the business of farming within their mineral rights' areas, the presence of 'fallow' land does not necessarily mean 'wasted' land, as it often is perceived from a commercial agriculture point of view (Kepe \& Tessaro 2014). This land may be used for cropping, grazing or a range of natural resource uses.

In Australia, Glencore's Liddell open cut coal mine has achieved high quality rehabilitation of grazing pastures. Grazing trials revealed cattle on the rehabilitated land grew faster and averaged an extra $79 \mathrm{~kg}$ over cattle on neighbouring pasture. At the abattoir, the extra weight and condition of the cattle grazed on rehabilitated land returned approximately 25 percent higher price. While the trial has not yet concluded, indications are the grazing of cattle on rehabilitated land at the Liddell coal mine is commercially viable and may provide superior pasture compared to surrounding unmined paddocks (Minerals Council of Australia 2016).

In China, changing climate in the Yanchang County has resulted in unique advantages for apple and pear growth (Zheng et al. 2014). Over the past decade, driven by changing climate patterns and its potential impact on food security for the increasing population, the Chinese Government has encouraged development and growth of the county's fruit industry. This has resulted not only in a stable agriculture-based income for local farmers but has also enabled farming away from sloped areas which were historically the only viable areas for agriculture in the county. It has also improved forest and grassland preservation (Zheng et al. 2014)

In Argentina, cultivation of the fish species pejerrey within the Paso de Piedra mine pit lake in the form of established aquaculture activities within flooded open pits, has proven feasible (Mallo et al. 2010). 
Aside from direct land impacts, mining activities could also increasingly affect agricultural production through the reduction in the supply and quality of water resources. This effect is both via direct environmental degradation and generation of mining-related pollution that impacts both nearby existing and potential future agricultural activities.

\subsubsection{Functional ecological systems}

Since the publication of the Millennium Ecosystem Assessment in 2005 there has been a surge of interest in ecological restoration to recover biodiversity, re-establish ecosystem functioning and connectivity and reactivate the delivery of ecosystem services (Blignaut et al. 2014). Ecosystem services have become an important concept in policy making, with decision makers having to trade-off competing demands for various benefits from agriculture, tourism and potable water from a broad range of stakeholders (De Groot 2005).

Land that is of great value for conservation is often also considered highly suitable for human use, resulting in competition between urban development and the protection of natural resources. Dorning et al. (2015) notes that maintaining ecological connectivity within human-modified (and rehabilitated) landscapes could encourage the movement and persistence of species, particularly under the threat of changing climate. Hence, mining-related rehabilitated areas offers an opportunity to improve the quality of landscapes outside of protected areas which can be important to species perseverance and at the same time provide important ecosystem functions.

\subsubsection{Energy}

Considering global political goals set for energy production, pressure on limited land resources will increase in the coming years, not only to provide raw materials for ambitious goals in renewable energy production and to substitute fossil resources, but also to feed an increasing world population. Accordingly, the demand for plant biomass offers new opportunities for agriculture and forestry.

However, conflicts between the different objectives of bioenergy development, ecosystem and biodiversity protection as well as landscape issues in particular become more and more obvious (Lupp et al. 2014). Despite their possible contribution to a reduction of greenhouse gas emissions, a non-selective and unregulated cultivation of crops grown for energy production has negative impacts not only on biodiversity, but can also lead to soil erosion, nutrient spill-overs and negative impacts on landscape aesthetics (Lupp et al. 2014). On the other hand, a connection between the production of bioenergy and irrigation exists, as farmers become fuel suppliers for powerplants, it becomes more important to achieve stable yields even in dry years (Gutzler et al. 2015).

Some mining companies have started using innovative approaches that simultaneously combine renewable energy with biogas and land rehabilitation. These projects also have co-benefits, such as soil remediation, carbon credit accumulation, reduced mine closure liability, reduced potential exposure to potential carbon taxes and job creation. For example, in South Africa, the Harmony Gold Mining Company has developed a long-term land rehabilitation strategy linked to creating carbon sinks on mining-impacted land. Instead of following standard rehabilitation practices, such as grassing, Harmony plants species such as sweet sorghum, sugar beet and giant king grass, all known for their high carbon sequestration potential. Harmony's rehabilitation strategy also includes planting energy crops on mine-impacted land that has zero economic value. Once harvested, these crops can be converted into renewable energy, in the form of biogas, through an anaerobic digestion process. The biogas will be used to replace fossil fuels in Harmony's metallurgical plants (Kotze 2014).

\subsubsection{Urban development}

To create opportunities for future-oriented long-term employment, new, innovative businesses require a good infrastructure e.g. offices, commercial real estate, comfortable and aesthetically pleasing housing, as well as recreational areas and cultural facilities. Identification and provision of such utilities and other supply infrastructure which can meet the requirements of business and local people therefore becomes an important 
planning component of the post-mining landscape. Most mining operations have established water, waste, power and road networks that could be seamlessly converted for alternative urban development.

\subsubsection{Macro-economic contribution}

Possibly one of the biggest challenges facing areas where GDP-contributing mines are approaching decommissioning and closure is the creation of alternative livelihood opportunities for the people who will remain in the area into the future. The degradation of 'ghost towns' due to closure of historic mining areas drive the need for a more proactive approach to the sustainable closure of mine sites.

During mining operations, while local people employed in mining obtain direct income as mining wages, nonminers in the local communities (either family members of miners, or other community members) obtain their income through different socio-economic activities, including sales from food crops or meat and/or other local business activities. Wages earned by employees at mining operations are spent on goods and services produced by local people, which, in turn, increases the incomes of local populations (Kitula 2006). Hence, mineral extraction in these areas results in development of communities in close proximity to the mine due to mining-related employment opportunities during operations. This, in turn, provides an economic base for further growth of these communities, as mine-worker spend increases.

The operational economic role which a mine has assumed in an area (even if this was not the intention) is foreseen to become a key land use planning driver. This is important when assessing the area's socioeconomic dependencies and the mine's associated long-term economic contributions within the rehabilitated, post-mining landscape. As so aptly described by Cousins \& Scoones (2010), all land within a mining rights' area should instead be seen as a basic livelihood asset from which multiple and diverse livelihoods may be derived.

\subsection{Prioritising land use drivers}

There is no defined hierarchy of importance for these land use drivers. However, Dale et al. (2000) suggested that a desired landscape mosaic be planned for according to basic human needs - first for water and biodiversity (ecosystem goods and services); then for cultivation, grazing and wood products (food security); and finally, for homes and industry (shelter). This is roughly prioritised in terms of Maslow's hierarchy of human needs (Figure 2), where basic human needs underpin the need for supporting psychological supporting structures.

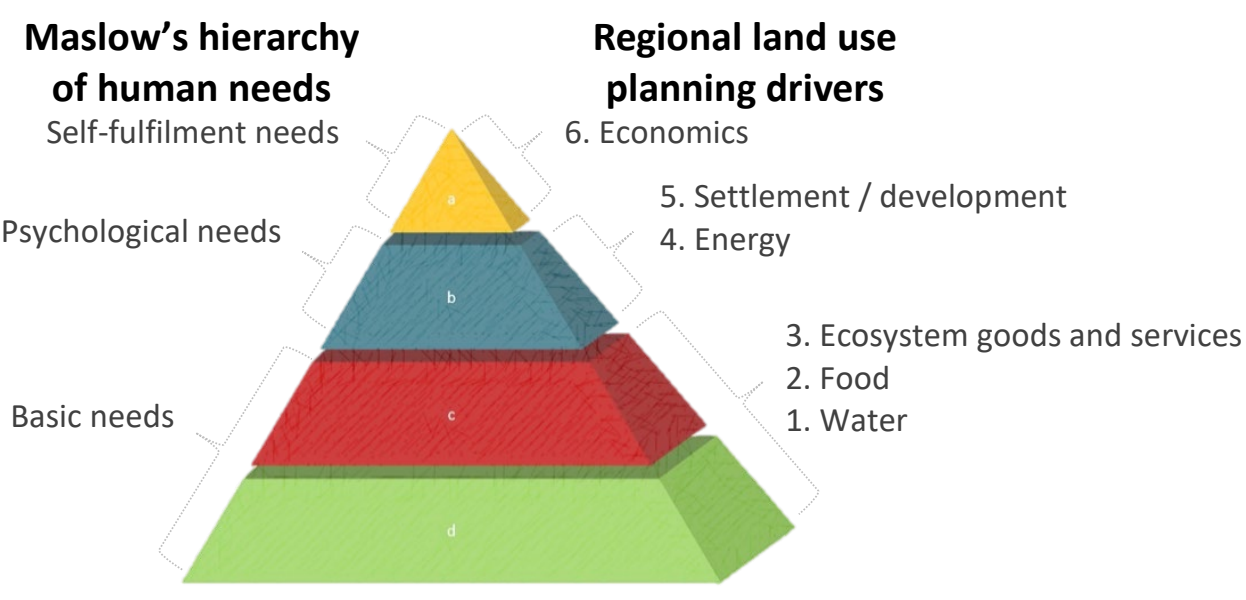

Figure 2 Land use planning regional drivers, prioritised in terms of Maslow's hierarchy of human needs

Based on the global regional land use drivers identified, it is evident that developed nations would be able to focus post-mining land uses higher up on this hierarchy, whilst developing nations are still challenged with providing basis needs around water and food. 


\subsection{The 'ifs', 'buts' and 'maybes' for regional mine closure integration}

By incorporating land use planning as an integral component of mine planning, the suitability of the mine plant, infrastructure, associated rehabilitated facilities, as well as surrounding land within the mining rights boundary, can be assessed for specific characteristics that could either enhance or impact on the site, adjacent or regional land uses. A well thought-through rehabilitated landscape could offer the same or higher value to remaining communities post-mining, whether this be in monetary value or socially-acceptable ecosystem goods and services. This value could be even higher if regional corridors of these and similar goods and services can be interlinked across landscapes adjacent to the rehabilitated mine.

Furthermore, by understanding a site's current and long-term rehabilitation-related risks, questions such as 'Can the land be used for its prior use after the mine has closed?' and 'If not, what alternative uses are appropriate?' can be defined upfront in the mine planning process, with suitable rehabilitation measures put in place. Regional planning needs provide an opportunity for incorporation of novel, economically-feasible land use options that could also manage or mitigate long-term environmental and social impacts associated with the rehabilitated site.

The earlier post-mining land use planning is incorporated as part of mine and associated rehabilitation planning, the greater the opportunity for recreation of a diversity of functional alternative land uses, aligned to stakeholder expectations.

However, the relationship between land planning-related policy and land mining rehabilitation can only be achieved via an interdisciplinary approach including a multitude of technical, planning and social stakeholders (Han \& Zhang 2014). Application of integrated land rehabilitation methods to solve regional land use problems and land rehabilitation disciplines need to be established to take full advantage of land resources and to resolve the land use issues linked to socio-economic development.

It is becoming necessary to explore alternate ways of sustaining the affected communities in post-mining regions, more so in the face of increased pressure to ensure long-term food security globally. With current political attention on the need to improve the overall socio-economic conditions in host countries, rehabilitation planning will need to focus more emphatically on ensuring incorporation of key elements for creation of a beneficial, post-mining positive legacy. Successful implementation of the most feasible postmining land use, or suite of uses, is only possible through consultation with- and incorporation of stakeholder views and knowledge. This remains possibly the most challenging aspect of a mine's planning domain. Defining the land's and people's needs for a post-mining landscape, which is often more than 20-30 years into the future, early on in a mine planning process requires foresight into changing localised and regional needs. It also requires compassion and understanding as stakeholders can often be emotive in their thinking. This aspect does not imply that a mine should focus its land use planning purely on stakeholder views, opinions and needs, but instead encourages ongoing transparent integration of these views into the planning process, throughout the mine's life. Building such relationships will improve stakeholders' understanding of the mine's rehabilitation and land use challenges. Should changes in the post-mining land uses be required, this understanding could be used to support and assist in identification of viable alternatives.

\section{Conclusion}

By incorporating land use planning as an integral component of mine planning, the suitability of the mine plant, infrastructure, associated rehabilitated facilities (such as waste rock dumps and backfilled pits), as well as surrounding land within the mining rights boundary, can be assessed for specific characteristics that could either enhance or impact on the next land use. This could include assessing the suitability for use, safety, potential for environmental impact and the associated cost of retrofitting the specific mining assets for future use. It also would consider most suitable placement of infrastructure and location of long-term landscape components such as final voids or hazardous waste facilities. It is likely that not all assets will be fit for purpose for the next land use and some expenditure will be required to either renovate or refurbish the asset prior to re-use or transfer. In this regard, the possibility of future mining and/or reprocessing opportunities either 
onsite and within the greater regional operations and the possible extended use of existing infrastructure could also be considered.

The defined post-mining land use goal should take into consideration local, regional and national land planning needs. Consideration of regional land use needs implies undertaking rehabilitation within as large a geographical footprint area as possible; not just within site boundaries. It also implies that adjacent sites and, even, larger geographical mining complexes can work together to recreate defragmented landscapes that have a larger ecological, agronomic and/or social positive influence. Ultimately, none of these land uses occur as standalone landscapes and, by the nature of continual land use change, land use planning on the mines should consider the best possible mix of these uses within their planning boundaries.

\section{References}

Australian Renewable Energy Agency 2019, 'South Australian zinc mine to be converted into Australia's first compressed air facility for renewable energy storage', ARENA Wire, viewed 15 February 2019, https://arena.gov.au/news/south-australian-zincmine-to-be-converted-into-australias-first-compressed-air-facility-for-renewable-energy-storage/

Benchmark Foundation 2014, Policy Gap 9, South African Coal Mining - Corporate Grievance Mechanisms, Community Engagement Concerns and Mining Impacts, Johannesburg.

Binns, JA \& Nel, E 2003, 'The village in a game park: local response to the demise of coal mining in Kwa-Zulu Natal, South Africa', Economic Geography, vol. 79, p. 41.

Blignaut, J, Aronson, J \& De Wit, M 2014, 'The economics of restoration: looking back and leaping forward', Annals of the New York Academy of Science, vol. 1322, pp. 35-47.

Bloodworth, AJ, Scott, PW \& McEvoy, FM 2009, 'Digging the backyard: mining and quarrying in the UK and their impact on future land use', Land Use Policy, vol. 26S, pp. S317-S325.

Botha, I 2014, Aquaponics as a Productive Rehabilitation Alternative in the Mpumalanga Highveld Coalfields, masters' thesis, University of Bloemfontein, Bloemfontein.

Bowie, L \& Fulcher, J 2017, 'Planning for post-mining land uses', Planning Institute of Australia (Qld) Annual Conference 2017, Planning Institute of Australia, Bundaberg.

Boyer, J 2015, 'Mine closure: Canada's policy framework', Intergovernmental Forum on Mining, Minerals, Metals and Sustainable Development, International Institute for Sustainable Development, Winnipeg.

Brumfitt, IM 2013, Reconciling mining and Land use Planning Law: Challenges Facing Cooperative Governance in South Africa, masters' thesis, University of Cape Town, Cape Town.

Bureau for Food \& Agricultural Policy 2015, The Balance of Natural Resources: Understanding the Long-Term Impact of Mining on Food Security in South Africa, Pretoria.

Cao, X 2007, 'Regulating mine land reclamation in developing countries: the case of China', Land Use Policy, vol. 24, pp. $472-483$.

Chaminuka, P, Udo, HMJ, Eilers, K \& van der Zijpp, A 2014, 'Livelihood roles of cattle and prospects for alternative land uses at the wildlife/livestock interface in South Africa, Land Use Policy, vol. 38, pp. 80-90.

Choi, Y \& Song, J 2016, 'Sustainable development of abandoned mine areas using renewable energy systems: a case study of the photovoltaic potential assessment at the tailings dam of abandoned Sangdong Mine, Korea', Sustainability, vol. 8, no. 1320, https://dx.doi.org/10.3390/su8121320

Comp, TA 2013, 'From environmental liability to community asset: mined land reclamation', in M Tibbett, AB Fourie \& C Digby (eds), Proceedings of the Eight International Mine Closure Conference, Australian Centre for Geomechanics, Perth, pp. 415-422.

Cousins, B \& Scoones, I 2010, 'Contested paradigms of 'viability' in redistributive land reform: perspectives from Southern Africa', Journal of Peasant Studies, vol. 37, no. 1, pp. 31-66.

Cummings, J 2014, 'The mining industry and land rehabilitation in Australia - once were leaders', Journal of Cleaner Production, vol. 84 , pp. 39-40.

D'Souza, G, Miller, D, Semmens, K \& Smith, D 2003, 'Mine water aquaculture as an economic development strategy: linking coal mining, fish farming, water conservation and recreation', Aquaculture America Conference, https://doi.org/10.1300/J028v15n01_08

Dale, VH, Brown, S, Haeuber, RA, Hobs, NT, Huntly, N, Naiman, RJ, ... Valone, TK 2000, 'Ecological principles and guidelines for managing the use of land', Ecological Applications, vol. 10, no. 3, pp. 639-670.

Danielson, L \& Nixon, M 2010, 'Current Regulatory Approaches to Mine Closure in the United States', in A Warhurst \& L Noronha (eds), Environmental Policy in Mining: Corporate Strategy and Planning for Closure, Lewis Publishers, Boca Raton.

De Groot, R 2005, 'Function-analysis and valuation as a tool to assess land use conflicts in planning for sustainable, multi-functional landscapes', Landscape and Urban Planning, vol. 75, iss. 3-4, pp. 175-186.

Department of Minerals and Energy 2008, Regional Gold Mining Closure Strategy for the Witwatersrand Basin, Sustainable Development through Mining Project Reports, Council for Geoscience Report No. 2008-0179, Pretoria.

Doley, D, Audet, P \& Mulligan, D 2012, 'Examining the Australian context for post-mined land rehabilitation: reconciling a paradigm for the development of natural and novel ecosystems among post-disturbance landscapes', Agriculture, Ecosystems and Environment, vol. 163, pp. 85-93. 
Dorning, MA, Koch, J, Shoemaker, DA \& Meentemeyer, RK 2015, 'Simulating urbanization scenarios reveals trade-offs between conservation planning strategies', Landscape \& Urban Planning, vol. 136, pp. 28-39.

Evidence and Lessons from Latin America 2010, Land use Planning for Extractives Industries - Policy Brief, viewed 2 September 2018, http://ella.practicalaction.org/wp-content/uploads/files/120517_ECO_ExtIndLanUse_BRIEF2.pdf

German Federal Ministry for Economic Cooperation and Development 2011, Land use Planning - Concept, Tools and Applications, Eschborn.

Gulati, M, Jacobs, I, Jooste, A, Naidoo, D \& Fakir, S 2013, 'The water-energy-food security nexus: challenges and opportunities for food security in South Africa', Aquatic Procedia, vol. 1, pp. 150-164.

Gutzler, C, Helming, K, Balla, D, Dannowski, R, Deumlich, D, Glemnitz, M, ... Zander, P 2015, 'Agricultural land use changes a scenario-based sustainability impact assessment for Brandenburg, Germany', Ecological Indicators, vol. 48, pp. 505-517.

Hall, J 2018, Genex Secures Funding for Hydro Project, viewed 15 February 2019, https://www.genexpower.com.au/uploads/6/6/ 1/2/6612684/genex_secures_funding_for_hydro_project.pdf

Han, J \& Zhang, Y 2014, 'Land policy and land engineering', Land Use Policy, vol. 40, pp. 64-68.

Hancox, PJ 2016, 'The coalfields of South-Central Africa: a current perspective', Episodes, Journal of International Geoscience, vol. 39, no. 2, pp. 407-428.

Isolde, R 2009, 'Brown coal planning as a basis for sustainable settlement development', Procedia Earth and Planetary Science, vol. 1 , pp. 857-867.

Jeronimo, RP, Rap, E \& Vos, J 2015, 'The politics of land use planning gold mining in Cajamarca, Peru', Land Use Policy, vol. 49, pp. 104-117.

Jones, CE \& Maclean, MIA 2013, 'Reclaimed landscapes - incorporating cultural values', in M Tibbett, AB Fourie \& C Digby (eds), Proceedings of the Eight International Mine Closure Conference, Australian Centre for Geomechanics, Perth, pp. 441-446.

Kabir, SM, Rabbie, F, Chowdhury, MB \& Akbar, D 2015, 'A review of mine closure planning and practice in Canada and Australia', World Review of Business Research, vol. 5, no. 3, pp. 140-159.

Kepe, T \& Tessaro, D 2014, 'Trading-off: rural food security and land rights in South Africa', Land Use Policy, vol. 36, pp. 267-274.

Kitula, AGN 2006, 'The environmental and socio-economic impacts of mining on local livelihoods in Tanzania: a case study of the Geita District', Journal of Cleaner Production, vol. 14, iss. 3-4, pp. 405-414.

Kivinen, S 2017, 'Sustainable post-mining land use: are closed meta mines abandoned or re-used space?', Sustainability, vol. 9 , no. 1705, https://dx.doi.org/10.3390/su9101705

Kotze, C 2014, 'Biogas power generation has huge potential for post-mining land use', Mining Weekly, 7 November 2014, pp. 9-13.

Lane, A \& Ndlovu, J 2012, 'The promise of Africa', Proceedings of the XXVI International Mineral Processing Congress, International Mineral Processing Congress, Rhondebosch.

Larondelle, N \& Haase, D 2012, 'Valuing post-mining landscapes using an ecosystem approach - an example from Germany', Ecological Indicators, vol. 18, pp. 567-574.

Latimer, C \& Hannam, P 2018, 'AGL to transform coal mine to pumped hydro for Liddell shortfall', viewed 15 February 2019 , https://www.smh.com.au/business/companies/agl-to-transform-coal-mine-to-pumped-hydro-for-liddell-shortfall20180525-p4zhgr.html

Lilieholm, RJ, Cronan, CS, Johnson, ML, Meyer, SR \& Owen, D 2012, Alternative Futures Modelling in Maine's Penobscot River Watershed: Forging a Regional Identity for River Restoration, Lincoln Institute of Land Policy Working Paper, Lincoln Institute Project Code: WP12R, Lincoln Institute of Land Policy, Massachusetts.

Limpitlaw, D \& Briel, A 2013, 'Post-mining land use opportunities in developing countries', Proceedings of the Mining, Environment and Society Conference, The South African Institute of Mining and Metallurgy, Johannesburg, pp. 10-12.

Lottermoser, BG 2011, 'Recycling, reuse and rehabilitation of mine wastes', Elements, vol. 7, pp. 405-410.

Lupp, G, Steinhauber, R, Starick, A, Gies, M, Bastian, O \& Albrecht, J 2014, 'Forcing Germany's renewable energy targets by increased energy crop production: a challenge for regulation to secure sustainable land use practices', Land Use Policy, vol. 36, pp. 296-306.

Maczkowiack, B \& Smith, C 2012, 'Risk assessment models for post-mining land use', Proceedings of Life-of-Mine 2012, Australian Institute of Mining and Metallurgy, Melbourne.

Maczkowiack, B, Smith, CS, Slaughter, GJ, Mulligan, DR \& Cameron, DC 2012, 'Grazing as a post-mining land use: a conceptual model of the risk factors', Agricultural Systems, vol. 109, pp. 76-89.

Mallo, JC, De Marco, SG, Bazzini, SM \& Del Rio, JL 2010, 'Aquaculture: an alternative option for the rehabilitation of old mine pits in the Pampasian Region, Southeast of Buenos Aires, Argentina', Mine Water and the Environment, vol. 29, no. 4, pp. $285-293$.

Marra, M, Keene, T, Skousen, JG \& Griggs, T 2013, 'Switchgrass yield on reclaimed surface mines for bioenergy production', Journal of Environmental Quality, vol. 42, no. 3, pp. 696-703, https://dx.doi.org/10.2134/jeq2012.0453

Marvey, B 2009, 'Oil crops in biofuel applications: South Africa gearing up for a bio-based economy', Journal for Transdisciplinary Research in Southern Africa, vol. 5, https://dx.doi.org/10.4102/td.v5i2.132

Minerals Council of Australia 2016, Mine Rehabilitation in the Australian Minerals Industry, Kingston.

Morrisen-Saunders, A, Gorey, P, Doepel, D, Mregha, H \& McHenry, MP 2014, 'Enhancements in mine closure planning in Western Australia and possible applications for Africa', in IM Weiersbye, AB Fourie, M Tibbett \& K Mercer (eds), Proceeding of the Ninth International Mine Closure Conference, Australian Centre for Geomechanics, Perth.

Norman, LM, Feller, M \& Villarreal, ML 2012, 'Developing spatially explicit footprints of plausible land use scenarios in the Santa Cruz Watershed, Arizona and Sonora', Landscape and Urban Planning, vol. 107, pp. 225-235.

Otchere, F, Veiga, M, Hinton, J, Farias, R \& Hamaguchi, R 2004, 'Transforming open mining pits into fish farms: Moving towards sustainability' Natural Resources Forum, vol. 28, pp. 216-223. 
Palmer, A 2016, '15 Adaptive re-uses for old mines', Mental Floss, 15 March, http://mentalfloss.com/article/76571/15-adaptive-reuses-old-mines

Pearman, G 2009, 101 Things to do with a Hole in the Ground, Post-Mining Alliance, Eden Project, Cornwall.

Picarelli, S, Resende, A, Vieria, G, Costa, FL \& Goncales, JA 2014, 'Opportunities for future use in mine closure', Proceedings of Mine Closure Solutions 2014, p. 7.

Pijpers, R 2014, 'Crops and carats: exploring the interconnectedness of mining and agriculture in Sub-Saharan Africa', Futures, vol. 62, pp. 32-39.

Polster, D 2011, Natural Processes: Restoration of Drastically Disturbed Sites, Polster Environmental Services Ltd, British Columbia.

Resende, AG, Picarelli, S, Vieira, G, Costa, FL \& Chiodeto, B 2014, 'Regional closure plans for iron ore mines: a new approach', InfoMine, Proceedings of Mine Closure Solutions 2014, Brazil, presentation.

Sibanda, L \& Broadhurst, JL 2018, 'Exploring an alternative approach to mine waste management in the South African gold sector', in C Wolkersdorfer, L Sartz, A Weber, J Burgess \& G Tremblay (eds), Proceedings of the Eleventh ICARD Conference, International Mine Water Association, Pretoria, pp. 849-856.

Song, J \& Choi, Y 2016, 'Analysis of the potential for use of floating photovoltaic systems on mine pit lakes: case study at the Ssangyong open-pit limestone mine in Korea', Energies, vol. 9, no. 102, https://dx.doi.org/10.3390/en9020102

Sudo, C 2017, '5 repurposed mines and quarries that will blow your mind', Bisnow, 22 September, https://www.bisnow.com/ national/news/construction-development/5-adaptive-reuses-of-mines-and-quarries-that-will-blow-your-mind-79452

Tibbet, M, Mulligan, D \& Audet, P 2012, 'Recent advances in restoration ecology: examining the modern Australian agro-ecological and post-mining landscapes', Agriculture, Ecosystems and Environment, vol. 163, pp. 1-2.

Van Zyl, D, Agioutantis, Z \& Joyce, S 2016, 'Waste note, want not - rethinking the tailings and mine waste issue', AusIMM Bulletin, December 2016, viewed 15 February 2019, https://www.ausimmbulletin.com/feature/waste-not-want-not-rethinking-thetailings-and-mine-waste-issue

Wang, J 2012, 'Study on sustainable utilization strategy of the mining wastelands', Procedia Environmental Sciences, vol. 16, pp. 764-768.

Weatherhead, EK \& Howden, NJK 2009, 'The relationship between land use and surface water resources in the UK', Land Use Policy, vol. 26S, pp. S243-S250.

Woodruff, SC \& Bendor, TK 2016, 'Ecosystem services in urban planning: comparative paradigms and guidelines for high quality plans', Landscape and Urban Planning, vol. 152, pp. 90-100.

$\mathrm{Wu}, \mathrm{X}, \mathrm{Zuo}, \mathrm{X}$ \& Fang, Y 2011, 'Evaluation of reclamation land productivity in mining districts', Transactions of the Nonferrous Metallurgical Society of China, vol. 21, pp. 717-722.

Zheng, N, Fu, B, Lu, Y \& Zheng, Z 2014, 'Changes of livelihood due to land use shifts: a case study of Yanchang County in the Loess Plateau of China', Land Use Policy, vol. 40, pp. 28-35. 
